\title{
KATSAUS VUOROVAIKUTUKSEEN ÄÄNTÖVÄYLÄN JA ÄÄNILÄHTEEN VÄLILLÄ
}

\author{
Anne-Maria Laukkanen, Puheen ja äänen tutkimuksen \\ laboratorio, Yhteiskuntatieteiden tiedekunta, \\ Tampereen yliopisto
}

\section{Unto K. Laine, Signaalinkäsittelyn ja akustiikan laitos, Aalto-yliopisto}

\begin{abstract}
Puheen ja äänen tuottoa tarkastellaan usein yhä edelleen perinteisen nelijakomallin mukaan, jossa hengityselimistö, äänihuulet, ääntöväylä ja huuliaukko toimivat itsenäisinä yksiköinä. Todellisuudessa kuitenkin ääntöväylän muodostama resonaattori on vuorovaikutuksessa molempien päätepisteidensä, äänihuulten ja huuliaukon, kanssa. Tässä katsauksessa kuvataan keskeiset vuorovaikutuksen muodot ja annetaan esimerkkejä niiden toteutumisesta. Interaktion voidaan todeta toteutuvan niin ääniharjoitteissa, taiteellisessa äänenkäytössä kuin äänihäiriöissäkin. Käytännön esimerkit opastavat myös tunnistamaan, miltä interaktion toteutuminen tuntuu kehossa.
\end{abstract}

Avainsanat: impedanssi, käheys, laulaminen, reaktanssi, resonanssi, ääniterapia

\section{JOHDANTO}

Tämä katsausartikkeli rakentuu aiemmin julkaistun version (Laukkanen, 2009) pohjalle uudistaen ja täydentäen sitä. Teemaa avataan niin varhaisten kuin aivan tuoreiden tutkimustulosten avulla ja havainnollistetaan käytännön esimerkkien avulla.

Puheentuoton klassisissa akustisissa teorioissa soinnillisten äänteiden tuottomekanis-

\footnotetext{
Kirjoittajien yhteystiedot:

Anne-Maria Laukkanen

Unto K. Laine

anne-maria.laukkanen@uta.fi

unto.laine@aalto.fi
}

min muodosti neljä itsenäisestä osatekijä: generaattori eli voiman lähde (hengityselimistö), värähtelijä (äänihuulet), suodatin (ääntöväylä eli kurkunpääontelon, nielun, suu- ja nenäontelon muodostama kokonaisuus) sekä huuliaukko, josta ääni säteilee paineaaltona ympäristöön (Fant, 1960). Näiden osien katsottiin toimivan itsenäisesti, ilman merkittävää akustista vuorovaikutusta. Ääntöväylän muodostama resonaattori on kuitenkin jatkuvassa akustisessa vuorovaikutuksessa sen päätepisteiden (ns. terminaalien) muodostamien rakenteiden kanssa. Resonaattorin alkupäässä äänihuulet ja -rako ja loppupäässä huuliaukko vaikuttavat merkittävästi väylän resonanssien taajuus- ja amplitudiominaisuuksiin. 
Näillä puolestaan on suoria vaikutuksia mm. äänihuulten yläpuoliseen paineeseen ja siten myös äänihuulten värähtelyyn.

Artikulaation muuttaessa ääntöväylän profiilia sen resonanssien taajuudet ja amplitudit muuttuvat, eli väylä muokkaa ääntä siten, että resonanssien ympäristössä olevat taajuudet voimistuvat ja niistä etäämmällä olevat taas vaimenevat. Niin kauan kuin äänihuulten tarjoama vastus keuhkoista tulevalle ilmavirralle on selvästi suurempi kuin ääntöväylän vastus, on ääntöväylän (ja henkitorven) vaikutus äänentuottoon pieni. Ääntöväylän akustiikan (sen resonanssien) vaikutus äänentuottoon tulee ilmeiseksi tilanteissa, joissa ääntöväylän vastus ilmavirtaukselle kasvaa. Niin käy tuotettaessa puolisuljettuja äänteitä (suppeat tai pyöreät vokaalit kuten /i, y, u, o, ö/, soinnilliset hälyäänteet kuten esimerkiksi /v, z/ ja nasaalit /m, n, ng/) sekä soinnillisia (kokonaan tai osa-aikaisesti) suljettuja äänteitä (umpija täryäänteet kuten esim. /b, d, g, r/) sekä silloin, kun perustaajuus (sävelkorkeus, jolla äännetään) nousee ääntöväylän alimmalle resonanssitaajuudelle (puhuttaessa, huudettaessa tai laulettaessa sävelkorkeuksilla noin $\mathrm{e}^{1}$ :stä ylöspäin).

Huuliaukko vaikuttaa ääntöväylän sisällä olevaan ja sieltä ulos säteilevään akustiseen energiaan (ks. Laine, 1982). Yleisesti ottaen, kun ääni säteilee ulos huuliaukosta, ääntöväylän sisällä oleva äänienergia vaimenee $n$. $6 \mathrm{~dB}$ per oktaavi, kun taas ääntöväylän ulkopuolella tilanne on päinvastainen: Äänen korkeammat osasävelet säteilevät ulos n. 6 $\mathrm{dB} /$ oktaavi voimakkaampina. Huuliaukon koko säätelee ääntöväylässä olevan ja sieltä säteilevän akustisen energian suhdetta. Suuri huuliaukko (avoimet /a, ä/) säteilee voimakkaasti, jolloin ääntöväylän resonanssit vaimenevat etenkin suuremmilla taajuuksilla (f $>1 \mathrm{kHz}$ ). Suppeissa vokaaleissa $(/ \mathrm{i}, \mathrm{y} /)$ säteily on heikompaa, jolloin resonanssit yli 1 $\mathrm{kHz}$ taajuuksilla ovat teräviä ja voimakkaita.
Vaikka merkittävää akustista vuorovaikutusta tapahtuu ääntöväylän kummassakin päätepisteessä, seuraavassa keskitytään tarkastelemaan äänentuoton kannalta tärkeintä, eli äänihuulten luona tapahtuvaa akustista interaktiota.

Interaktiivista puheentuoton mallia tarvitaan korkealaatuiseen puhe- ja laulusynteesiin ja epätavallisten, mm. tavallista parempien tai äänihäiriöihin liittyvien, äänenlaatupiirteiden tutkimiseen. Interaktiivinen malli auttaa osaltaan selittämään äänentuoton ongelmia tietyillä sävelkorkeuksilla äännettäessä. Se auttaa myös ymmärtämään äänen harjoittamisessa käytettyjä menetelmiä ja eri laulugenreissä valittuja äänentuottotapoja.

\section{VUOROVAIKUTUKSEN LAJIT}

\section{Akustisella interaktiolla tarkoitetaan ääntö-} väylän vaikutuksia ns. glottaaliseen ilmavirtauspulssiin eli siihen ilmavirtaukseen, joka purkautuu äänihuulten välistä niiden värähdellessä. (Akustis-) mekaaninen interaktio puolestaan tarkoittaa äänihuulten ylä- ja alapuolisen tilan resonanssien vaikutuksia itse äänihuulivärähtelyyn (Fant \& Lin, 1987).

Glottaalinen ilmavirtauspulssi voidaan saada selville käänteissuodatusmenetelmällä, jolla äänestä suodatetaan pois ääntöväylän resonanssien ja huuliaukon vaikutukset. Resonanssit aikaansaavat äänen osasävelten ja osasävelalueiden voimistumia, jotka lisäävät äänen voimakkuutta ja muuttavat sen väriä akselilla tummasta heleään ja viime kädessä määräävät esimerkiksi, mitä vokaaleja me äänessä kuulemme. Äänihuulten synnyttämien virtauspulssien spektri laskee noin $12 \mathrm{~dB}$ per oktaavi. Koska huuliaukko säteilee korkeampia taajuuksia ulospäin paremmin kuin matalia, mikrofoniin tai korvaan saapuvan äänen spektrin kaltevuus pienenee ollen enää noin $6 \mathrm{~dB}$ per oktaavi. Käänteissuodatuksessa poistetaan sekä huuliaukon aiheuttama spektrin kaltevuuden muutos että ääntöväylän resonanssit, jolloin jäljelle jää se ääni, joka on 
syntynyt äänihuulissa (Alku, 2011). Vaikka resonanssien vaikutukset eri taajuusalueisiin on äänestä poistettu kuvatun kaltaisella lineaariseen puheentuottomalliin perustuvalla menetelmällä, niin äänihuulten tuottama ilmavirtauspulssi on muokkaantunut myös useiden epälineaaristen tekijöiden vaikutuksesta, joita tämä yksinkertaistettu malli ei huomioi.

\section{Miten akustinen vuorovaikutus ilmenee}

Akustisella vuorovaikutuksella on erilaisia ilmenemismuotoja (Fant \& Lin, 1987): (1) Kallistuminen (skewing) tarkoittaa ilmavirtauspulssin muuttumista epäsymmetriseksi (virtauksen kasvuvaihe muuttuu hitaammaksi kuin sen vähenemisen vaihe). (2) Rippeli (ripple) viittaa glottispulssimuodon rosoisuuteen, pienten pullistumien ilmenemiseen (ks. Kuva 1). Käsite päällekkäistyminen tai summautuminen (superpositioning) tarkoittaa edellisten pulssien aikaisen äänienergian (lähinnä ääntöväylän resonansseihin liittyvän ilmanpaineenvaihtelun) summautumista tarkastelun kohteena olevaan pulssiin, ja se on syynä rippeliin - tai voi myös ilmetä vain 3 ) pulssin amplitudin (ilmavirtausmäärän) kasvuna. 4) Vaimeneminen (truncation) tarkoittaa ääntöväylän resonanssien vaimenemista ääniraon aukiolovaiheessa. Tämä ei vaikuta niinkään ilmavirtauspulssin muotoon, mutta kylläkin akustisen signaalin muotoon. Ilmiö havainnollistuu parhaiten resonanssien spektraalisten muotojen muutoksina. Resonanssitajuudet myös nousevat hieman, koska ääniraon ollessa auki ääntöväylä on jonkin aikaa molemmista päistä avoin putki, jonka resonanssitaajuudet ovat korkeammat kuin vain toisesta päästä auki olevan putken (jollainen ääntöväylä yleensä on soinnillisissa äänteissä, suljetun ääniraon toimiessa putken suljettuna päänä ja auki olevan suun tai sierainten toimiessa avoimena päänä.)
Akustisella vuorovaikutuksella voidaan selittää mm. sitä havaintoa, että äänihuulivärähtelyssä ääniraon pinta-ala vaihtelee täysin symmetrisesti, vaikka äänihuulista tuleva ilmavirtauspulssi on epäsymmetrinen (Rothenberg, 1981). Ääntöväylän ilmamassan hitausominaisuus, inertia (inertiivinen reaktanssi), aiheuttaa äänihuulista tulevan ilmavirtauspulssin kallistumista; ilmamassa vastustaa sen läpi kulkevaa virtausta jonkin aikaa ja sitten liikkeelle päästyään alkaa liikkua nopeammin, ja siten muotoilee ilmavirtauspulssia. Virtauspulssin kallistuminen voimistaa äänen osasäveliä (spektrin kaltevuus loivenee), ja äänestä tulee voimakkaampi ja kuuluvampi. Ahtautuma ääntöväylässä (kuten tuotettaessa suppeita vokaaleita tai soinnillisia hälyäänteitä) kasvattaa ääntöväylän reaktanssia ja siten glottispulssin kallistumista.

Myös summautuminen lisää yleensä äänen voimakkuutta. Kun perustaajuuden (F0) ja ääntöväylän matalimpien resonanssien välinen taajuussuhde on sopiva, tapahtuu energian samanvaiheinen (synkroninen) summautuminen. Epäedullisessa tapauksessa vanha ja uusi heräte voivat summautua vastakkaisvaiheisina, jolloin ääni vaimenee. Kun F0 liukuu, tapahtuu vuorotellen synkroninen vahvistuminen ja epäsynkroninen vaimeneminen, eli ääneen syntyy rippeliä. Rippeli voi vaikuttaa eri tavoin spektriin riippuen ääntöväylän resonanssitaajuuksien ja perustaajuuden suhteista. Spektri voi loiventua hieman (yläsävelet saavat vahvistusta) tai spektriin voi ilmestyä kuoppia, äänienergian vaimenemista, joillekin taajuuksille (vastakkaisvaiheisuus, ks. Kuva 1). Synteesikokeiden avulla on voitu todeta, että akustisen vuorovaikutuksen eri ilmenemismuodot saavat äänen kuulostamaan luonnollisemmalta. 
a)

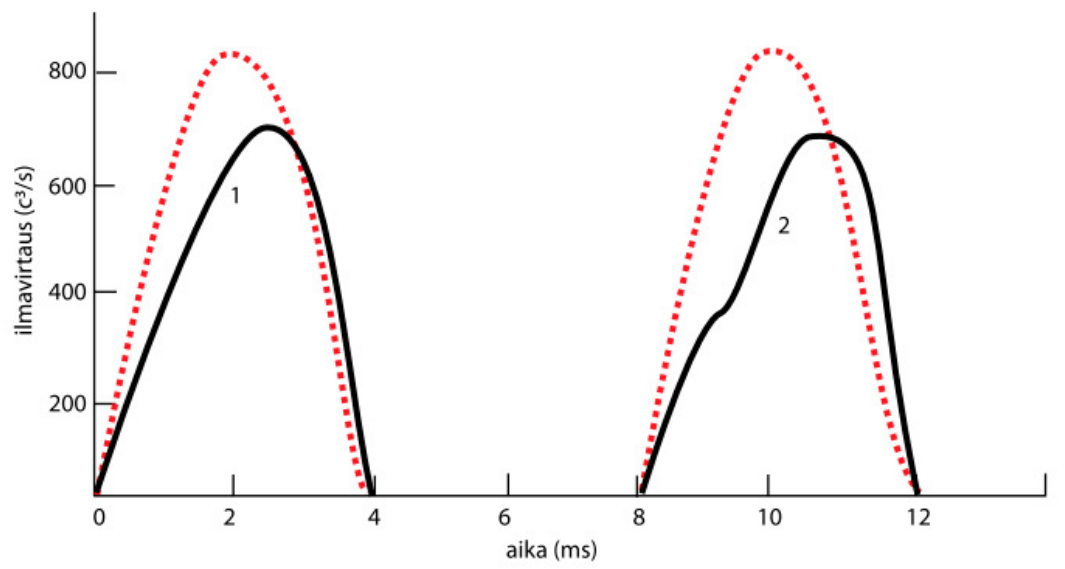

b)

$/ \mathrm{i} /$

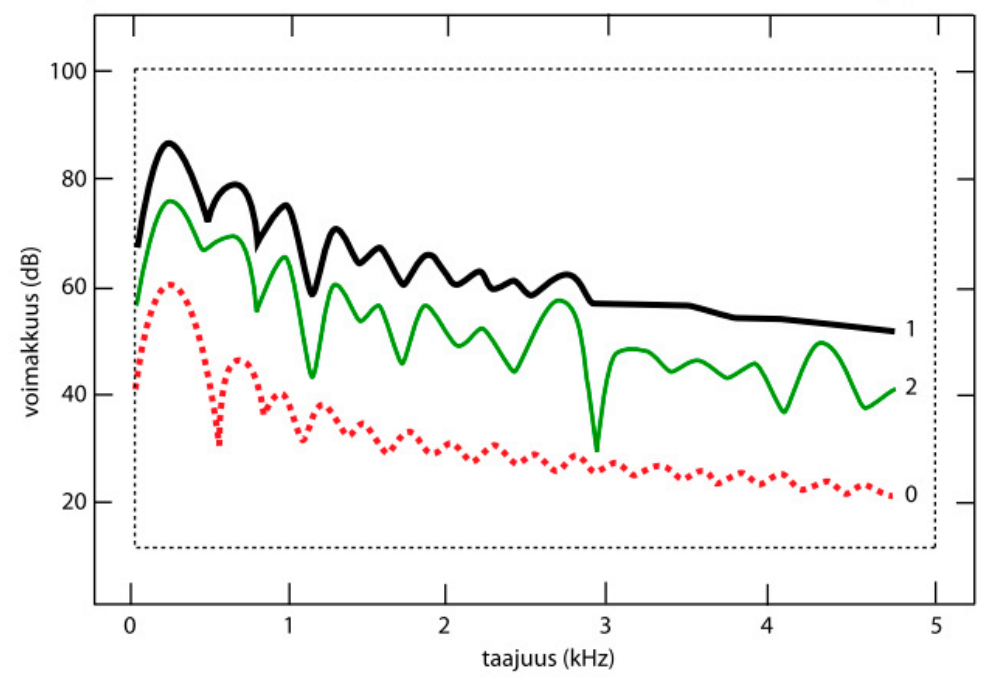

KUVA 1. Akustisen interaktion seurauksia (kallistuminen, rippeli ja niiden vaikutuksia spektriin). Kuva mukailtu Fantin ja Linin (1987) artikkelissa julkaistun perusteella. Ylempi kuva: Glottaalinen ilmavirtaus ajassa. Punainen katkoviiva: Glottaalinen ilmavirtaus, johon väylän interaktio ei ole vaikuttanut. Pulssimuoto on symmetrinen. Musta ehyt viiva, numero 1: Kallistuminen. Musta ehyt viiva, numero 2: Rippeliä näkyvissä. Alempi kuva: Vastaavat spektrit. Yläsävelet ovat vahvempia, kun väylän interaktio on vaikuttanut glottaaliseen ilmavirtaukseen (musta ja vihreä spektri).

\section{Tutkimuksia mekaanisesta vuorovaikutuksesta}

Jo 1800-luvulla ja sittemmin 1900-luvun alkupuolella, erityisesti Saksassa, tutkittiin äänihuulten ylä- ja alapuolisten tilojen akustiikan vaikutusta äänihuulivärähtelyyn. Johannes Müller (1837) teki kuolleiden ih- misten kurkunpäillä kokeita, joissa hän muutti äänihuulten ylä- ja alapuolelle asetettujen (ääntöväylää ja henkitorvea jäljittelevien) putkien pituutta ja siten niiden resonanssitaajuuksia. Hän totesi äänenlaadun muuttuvan joidenkin putkimuutosten seurauksena: Ääni alkoi ensin säristä ja siirtyi sitten rintarekisteristä falsettiin. Sittemmin on tehty lukuisia 
tutkimuksia, joissa on tarkasteltu tutkimushenkilöiden ääntöä eri sävelkorkeuksilla, eri vokaaleilla ja eripituisiin putkiin sekä tehty kokeita keinotekoisilla äänihuulilla, kuolleiden ihmisten tai eläinten kurkunpäillä ja viime aikoina erityisesti matemaattisella mallinnuksella. Näissä tutkimuksissa on varmistunut mm. se, että kun äänihuulten värähtelytaajuus osuu yksiin äänihuulten yläpuolisen putken resonanssien kanssa (joko sen tähden, ettääänen perustaajuutta on muutettu tai sen tähden, että ääntöväylän resonanssitaajuuksia on muutettu joko artikulaation avulla tai putkeen ääntämällä tai äänihuulten yläpuolelle asetetun putken pituutta muuttamalla) äänestä voi tulla epätasainen, särisevä ja myös perustaajuus saattaa nousta tai laskea. Jotkut tutkijat ovat päätelleet, etteivät äänihuulet voi värähdellä ääntöväylän resonanssitaajuudella (eritoten alimmalla ja vahvimmin toteutuvalla). Toisaalta mm. Sundberg on todennut, että laulaessaan korkeilla sävelkorkeuksilla sopraanolaulajat nostavat ääntöväylän alimman resonanssitaajuuden lähelle äänen perustaajuutta; tällöin he voivat saada jopa 30 dB lisää voimaa ääneen (Sundberg, 1975). Rothenbergin (1986) tulosten mukaan naislaulajan äänihuulivärähtely tehostuu perustaajuuden ja ääntöväylän resonanssin osuessa yksiin. Titze (1988) on laskennallisesti todennut, että ääntöväylän (tai henkitorven) resonanssi auttaa äänihuulivärähtelyä, jos sen resonanssin seurauksena äänihuulten yläpuolinen ilmanpaine on suuri siinä vaiheessa, kun äänihuulet lähtevät erkanemaan toisistaan ja pieni siinä vaiheessa, kun ne alkavat mennä yhteen. Tämä edistää äänihuulivärähtelyä (saa äänihuulet tekemään laajempaa liikettä ja siten tuottamaan voimakkaampaa ääntä). Näin käy esimerkiksi silloin, kun äänihuulivärähtelyn taajuus on vain hieman alempi kuin ääntöväylän matalimman resonanssin eli F1:n taajuus tai vähän vähemmän kuin puolet siitä. Päinvastaisessa tilanteessa (äänihuulten yläpuolisen ilmanpaineen ollessa pieni ääniraon avautuessa ja suuri sen sulkeutuessa) äänihuulivärähtely heikkenee, äänirako pyrkii jäämään auki ja ääntö siirtyy falsettirekisteriin. Tällainen tilanne on kyseessä esimerkiksi silloin, kun henkitorven matalin resonanssi on sama kuin äänihuulivärähtelyn perustaajuus. Titze onkin esittänyt, että henkitorven resonanssi selittäisi (ainakin osaksi) rintarekisterin ja falsettirekisterin välisen siirtymän, joka on miehillä ja naisilla samalla sävelkorkeusalueella (n. e eli $329 \mathrm{~Hz}$; ns. ensimmäinen ylimeno eli passaggio).

Laine ja Vilkman (1987) tutkivat kuolleiden ihmisten kurkunpäillä ääntöväyläresonanssien vaikutusta äänihuulivärähtelyyn. Kurkunpään yläpuolelle asetettiin putki simuloimaan ääntöväylää, ja kielen toimintaa jäljiteltiin asettamalla pieni puupalanen putkeen ja vaihtelemalla sen sijaintia (etäisyyttä äänihuulista tai putken suulta eli huuliaukosta). Tutkimuksessa saatiin vahvistusta sille, että ääntöväylän akustiikka sinällään vaikuttaa äänihuulivärähtelyyn: Joskus äänihuulivärähtely parani huomattavasti, kun palikka asetettiin ääntöväyläputken suuaukolle tai putken sisään. Tutkijat tulkitsivat, että palikka vahvisti äänihuulten yläpuolista ilmanpaineenvaihtelua, joka sitten vaikutti äänihuulivärähtelyyn.

Ääntöväylän ahtauma tai pidentäminen lisää ääntöväylän ilmamassan vastusta (inertiivistä reaktanssia), josta puhuttiin edellisessä kappaleessa akustisen vuorovaikutuksen aiheuttajana (Story, Laukkanen \& Titze, 2000). Se voi myös aiheuttaa mekaanista vuorovaikutusta eli vaikuttaa äänihuulivärähtelyyn, jos ahtautuma on niin tiivis, että se nostaa riittävästi äänihuulten yläpuolista ilmanpainetta suhteessa niiden alapuoliseen ilmanpaineeseen. Sopivansuuruinen ahtauma tehostaa äänihuulivärähtelyä. Sellainen ahtautuma, joka nostaa ääntöväylän ilmanpaineen samaksi kuin äänihuulten alapuolinen ilmanpaine, lo- 
pettaa äänihuulivärähtelyn kokonaan (esim. kun on tuotettu maksimaalisen pitkään soinnillista klusiilia kuten /b/:tä).

Erilaisissa äänihäiriöissä äänihuulten massa ja/tai jäykkyys on epäsymmetrinen, mistä seuraa äänihuulivärähtelyn epäsäännöllisyyttä (tavallista suurempaa periodipituuden ja/ tai -amplitudin vaihtelua), periodin kahdentumista (subharmoniaa) ja muunlaista diplo- tai multifoniaa (kahden tai useamman perustaajuuden yhtäaikaista esiintymistä), äänihuulivärähtelyn moodien (tavallaan modaalirekisteri- ja falsettirekisterityyppisten perusmoodien) vaihtelua tai kaoottista värähtelyä (Herzel, Berry, Titze \& Saleh, 1994; Titze, 2000). Ääni voi kuulostaa samealta tai käheältä, rahisevalta tai siinä voi kuulla kaksi tai useampia yhtäaikaisia sävelkorkeuksia. Särisevien ja diplofonisten äänien tutkimus on osoittanut, että äänihuulten ja ääntöväylän resonanssitaajuuksien välisellä vuorovaikutuksella voi olla merkitystä niiden syntymiselle (Mergell \& Herzel, 1997). Esimerkiksi diplofoniassa (bifonaatiossa) toinen äänihuuli saattaa synkronoitua värähtelemään ääntöväylän resonanssitaajuudelle.

Säriseviä, diplofonisia ja hälypitoisia äänenlaatuja voidaan saada aikaiseksi myös tahdonalaisesti, harjoittelemalla (Titze, 1998). Apuna voidaan käyttää esimerkiksi toista äänilähdettä (taskuhuulet, kurkunkansipoimu, kannurustot). Tämän tyyppisiä äänenlaatuja käytetään niin perinteisessä folkmusiikissa (Tiibetin munkkien laulu esim.) kuin nykyisessä kaupallisessa musiikissa tehokeinoina tai persoonallisen äänenlaadun aikaansaamiseen. Myöskin perinteinen jodlaus käyttää hyväksi ääntöväylän akustiikkaa (Echternach, Markl \& Richter, 2011). Laulaja vuorottelee väljemmän ja suppeamman vokaalin välillä, ja jälkimmäisessä $F 1$ :n lasku lähelle F0:aa edistää äänihuulivärähtelyn siirtymistä falsettiin.

\section{3 ÄÄNTÖVÄYLÄN \\ VIRTAUSVASTUKSEN JA RESONANSSIEN SUHDE}

Ääntöväylässä tapahtuu äänentuoton aikana ilmanpaineenvaihtelua samanaikaisesti monilla taajuuksilla, kaikilla, joita äänihuulivärähtely on tuottanut (perustaajuus ja sen kerrannaiset eli yläsävelet). Toiset näistä taajuuksista voimistuvat resonanssi-ilmiön vuoksi, toiset heikkenevät. Kuva 2 selventää ääntöväylän resonanssien ja vastuksen välistä yhteyttä. Ääntöväylän taajuusriippuva kokonaisvastus, eli impedanssin itseisarvo, on suurimmillaan resonanssitaajuuksilla, joilla myös ilmanpaineenvaihtelu on suurin. Niillä taajuuksilla ääntöväylässä on ns. seisova aaltoliike, ja äänihuulista tulevan ilmavirtauspulssin on kaikkein vaikein päästä ääntöväylän läpi. Resonanssitaajuuksia matalammilla taajuuksilla ääntöväylän vastus perustuu ilmamassan inertiaan, joka, kuten edellä on todettu, muotoilee äänihuulista tulevaa ilmavirtauspulssia ja lisää yläsävelten voimakkuutta, ja voi myös tehostaa äänihuulten värähtelyä. Tämä inertiivinen reaktanssi kasvaa, mitä lähemmäs resonanssitaajuutta mennään (Story ym., 2000). Ääntöväylän reaktanssi tukee äänentuottoa ns. rintarekisterissä, jossa äänihuulet värähtelevät koko syvyydeltään ja äänirako sulkeutuu tiiviisti äänihuulten mennessä yhteen. Heti resonanssitaajuuden saavuttamisen jälkeen (eli sitä hieman korkeammalla taajuudella) ääntöväylän reaktanssi muuttuu negatiiviseksi (kapasitiiviseksi, missä päätekijänä on ilman puristuvuus, eikä sen massa, kuten inertiivisessä tapauksessa), eikä ääntöväylä enää vastusta näillä taajuuksilla ilmavirtauspulssin etenemistä. Samalla ääntöväylän vaikutukset äänihuulivärähtelyyn pienenevät. Tämä tilanne edistää äänentuoton siirtymistä falsettiin eli värähtelytapaan, jossa äänirako pyrkii jäämään auki ja äänihuulet värähtelevät vain yläpinnoiltaan (ks. Titze, 2008). 


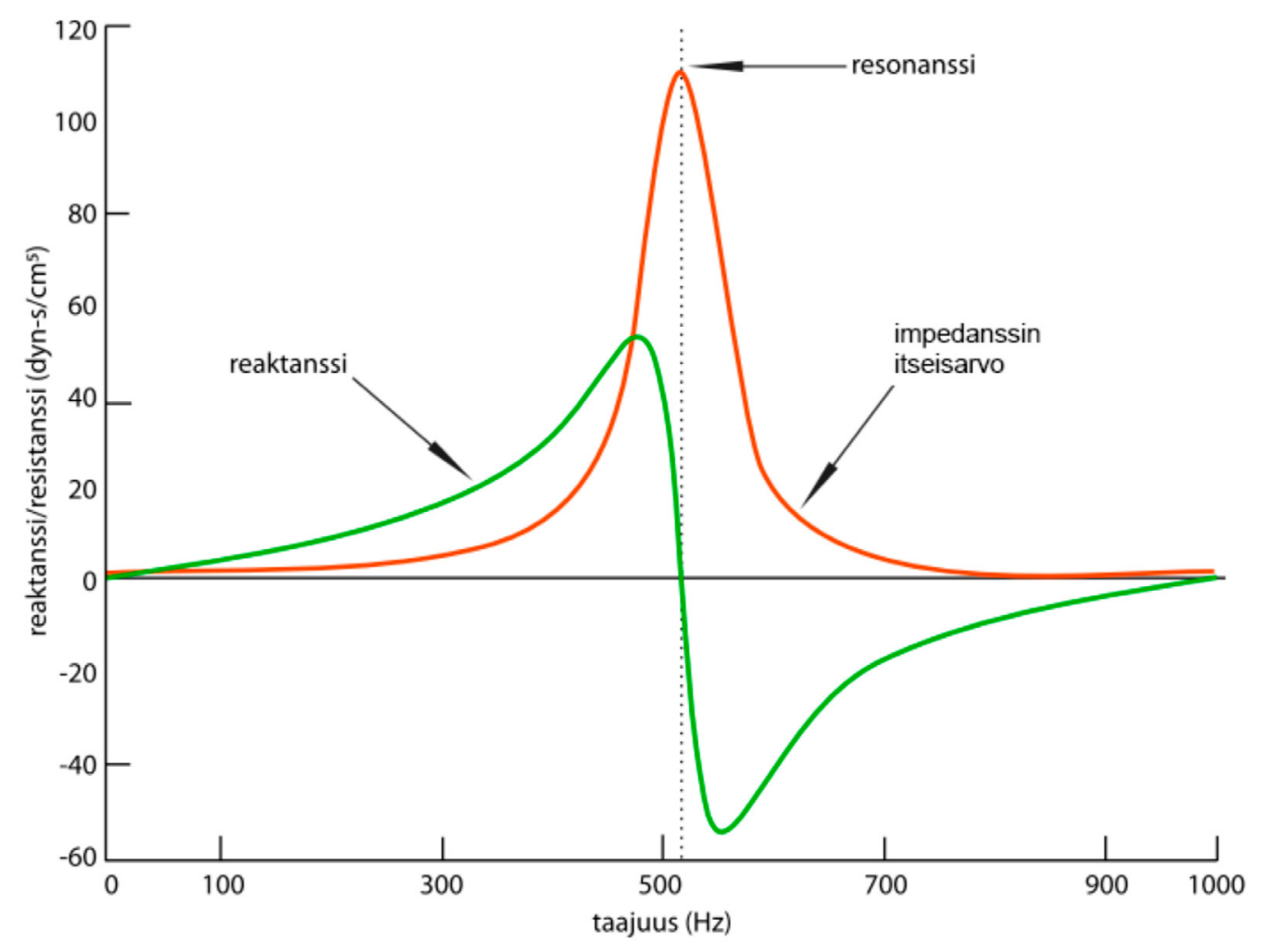

KUVA 2. Ääntöväylän yksittäisen (ensimmäisen) resonanssin taajuusominaisuudet, reaktanssi ja taajuusriippuva kokonaisvastus, eli impedanssin itseisarvo. Kuva mukailtu artikkelissa Story, Laukkanen ja Titze (2000) julkaistun perusteella. Katkoviiva = ääntöväylän resonans. sin taajuus. Punainen = impedanssin itseisarvo. Suurin resonanssitaajuudella. Vihreä = reaktanssi. Kasvaa resonanssitaajuutta lähestyttäessä (inertiivinen), mutta putoaa nollan alapuolelle heti sen saavuttamisen jälkeen (kapasitiivinen). Inertiivinen reaktanssi parantaa äänenlaatua ja äänihuulivärähtelyä.

\section{AKUSTINEN JA MEKAANINEN VUOROVAIKUTUS Ä̈̈NN HAR- JOITTAMISESSA}

Äänen harjoittamisessa käytetään paljon sellaisia äänteitä tai äänentuottotapoja, joissa ääntöväylää ahtautetaan ja/tai pidennetään (soinnilliset frikatiivit, nasaalit, päristely huulilla tai kielellä ja erilaisiin putkiin ääntäminen). Silloin ilmavirtaus ääntöväylästä hidastuu ja ääntöväylän ilmanpaine kasvaa. Ääntöväylän resonanssien aiheuttamat värähtelytuntemukset kitalaessa, huulissa ja kas- voissa voimistuvat. Äänentuotosta tulee tehokkaampaa, koska niin sanottu 'vuotoinen' ääntö, jossa äänihuulia lähennetään liian heikosti toisiaan kohden, tulee mahdottomaksi. Myöskin päinvastainen, äänihuulien liian voimakkaalla yhteen puristamisella tuotettava 'puristeinen' äänentuotto tulee vaikeaksi. Tämä lisää äännön taloudellisuutta eli pienentää äänihuuliin kohdistuvaa mekaanista kuormitusta äänihuulivärähtelyn aikana. Pidennettäessä tai ahtautettaessa ääntöväylää sen matalimman resonanssin taajuus laskee. 
Tämä merkitsee sitä, että ilmamassan inertiivinen reaktanssi kasvaa erityisesti puhekorkeusalueella (ks. Kuva 3). Tällä tavalla voidaan tehostaa äänihuulivärähtelyä. Ääntöväylän vastuksen kasvu voi lisätä myös ilmanpai- netta äänihuulten välissä ja estää niiden liian voimakasta yhteentörmäystä. Siten siis kyseisenlaiset harjoitukset antavat tuntuman tehokkaasta ja taloudellisesta äänentuotosta (Titze \& Laukkanen, 2007).

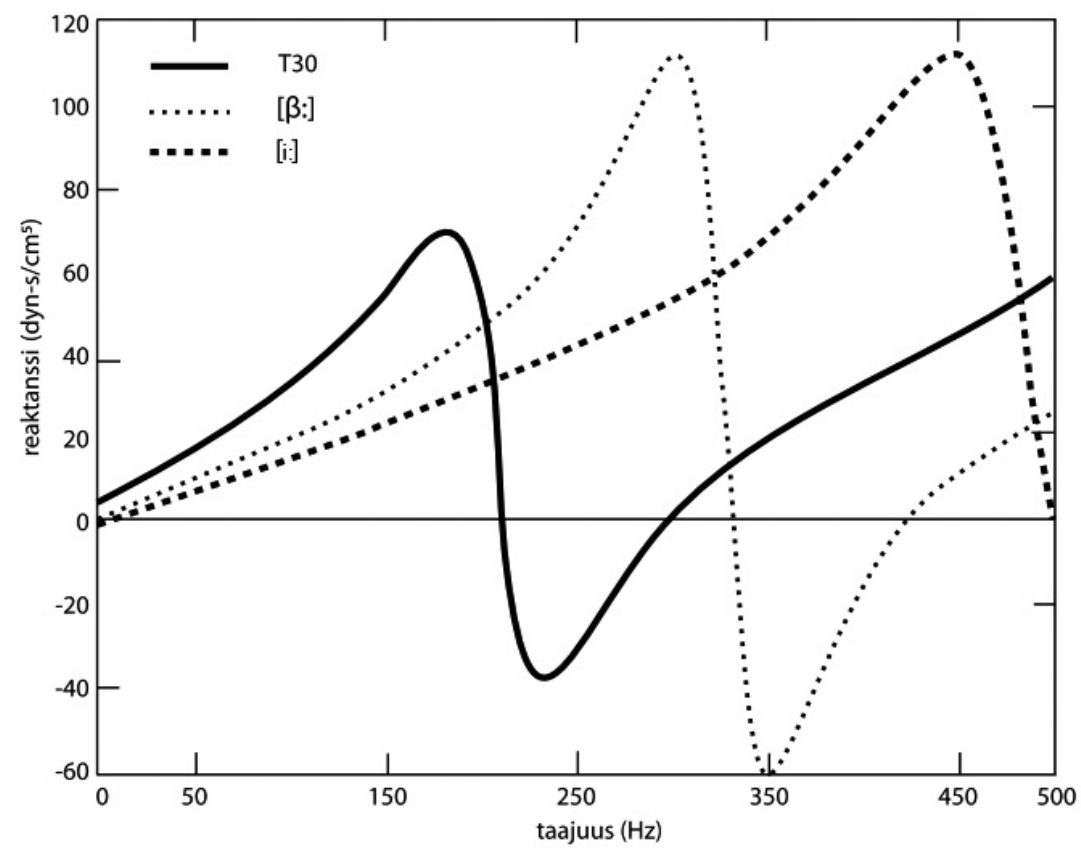

KUVA 3. Ääntöväylän reaktanssi tuotettaessa vokaalia [i:] (paksu pisteviiva) sekä kahta ääniharjoitusta: soinnillista bilabiaalista frikatiivia [ß:] (ohut pisteviiva) ja äännettäessä $30 \mathrm{~cm}$ pituiseen putkeen (vastaa ns. 'resonaattoriputkiin' eli Sovijärven putkiin ääntämistä; paksu ehyt viiva). Kuva mukailtu artikkelissa Story, Laukkanen ja Titze (2000) julkaistun perusteella. Ääntöväylän matalin resonanssi laskee molemmissa ääniharjoituksissa, ja reaktanssi kasvaa puhekorkeusalueella $(100-200 \mathrm{~Hz})$ verrattuna vokaaliääntöön.

Kuva 4 havainnollistaa, miten äänihuulivärähtely muuttuu akustis-mekaanisen vuorovaikutuksen seurauksena. Äänentuoton fysikaalisella mallilla aikaansaaduissa silmukkaesityksissä näkyy transglottaalisen paineen ja ääniraon pinta-alan vaihtelu yhden äänihuulivärähdyksen aikana. Transglottaalinen paine eli paine-ero äänihuulten alapuolisen ja yläpuolisen ilmanpaineen välillä on äänihuulivärähtelyn käyttövoima. Silmukkaesitys kuvassa 4 a (ääntö vokaalilla [u:]) alkaa tilanteesta, jossa äänirako on hieman auki (ajanhetki 1). Sen jälkeen ääniraon pinta-ala kasvaa, kunnes se saavuttaa maksimin (ajanhetki 5), minkä jälkeen äänirako alkaa sulkeutua. Ääniraon pinta-alan kasvaessa transglottaalinen paine pienenee ja saavuttaa minimin ajanhetkessä 7. Kun äänirako alkaa pienentyä, transglottaalinen paine alkaa kasvaa. Ajanhetkissä 15 ja 16 äänirako on täysin kiinni. Tämän jälkeen transglottaalinen paine nousee hyvin nopeasti ja saavuttaa maksimin juuri ennen kuin äänirako aukeaa jälleen. Silmukkaesitykset kuvissa 4 b ja c kuvaavat ääntöä resonanssiputkeen, jonka toinen pää on ilmassa (b) ja vedessä (c). Nämä silmukkaesitykset ovat selvästi 
erilaisia kuin kuvassa 4 a. Putkeen äännettäessä transglottaalinen paine ensin pienenee, kun ääniraon pinta-ala kasvaa, ja pysyy sitten lähes samana ääniraon sulkeutumiseen saakka (ajanhetket 11-21 kuvassa $4 \mathrm{~b}$ ja ajanhetket 10-19 kuvassa 4c). Silmukkaesitys havainnollistaa ilmavirtauksen tekemää työtä äänihuulivärähtelyssä. Kun silmukkaesityksen vaiheet kulkevat myötäpäivään, työ on positiivista eli virtausenergiaa kuluu äänihuulivärähtelyyn. Vokaaliäännössä virtausenergia kuluu siis kokonaisuudessaan äänihuulivärähtelyyn. Sen sijaan, kun silmukkaesityksen vaiheet kulkevat vastapäivään, työ on negatiivista eli äänihuulivärähtelyyn käytettävissä olevaa virtausenergiaa säästyy, koska osa äänentuottoon tarvittavasta ilmavirtausenergiasta korvautuu akustisella energialla. Tällöin siis ääntöväylän akustinen resonanssi tukee äänihuulivärähtelyä. Kun resonanssiputken ulompi pää on ilmassa, putken ja ääntöväylän F1 on lähellä äänihuulivärähtelyn perustaajuutta. Kun sen sijaan resonanssiputken ulompi pää on vedessä, sen ja (äänentuottomallin kovaseinämäisen) ääntöväylän F1 on lähellä veden kuplimistaajuutta (Horáček, Radolf \& Laukkanen, 2017, 2019). Ihmisen ääntöväylän seinämät ovat joustavat, eikä F1 laske yhtä alas kuin äänentuottomallilla putken ollessa vedessä. Ihmisellä F1 laskee lähelle äänihuulivärähtelyn perustaajuutta ja ääntöväylän seinämien akustis-mekaaninen resonanssi laskee lähelle veden kuplimistaajuutta (Horáček ym., 2017).
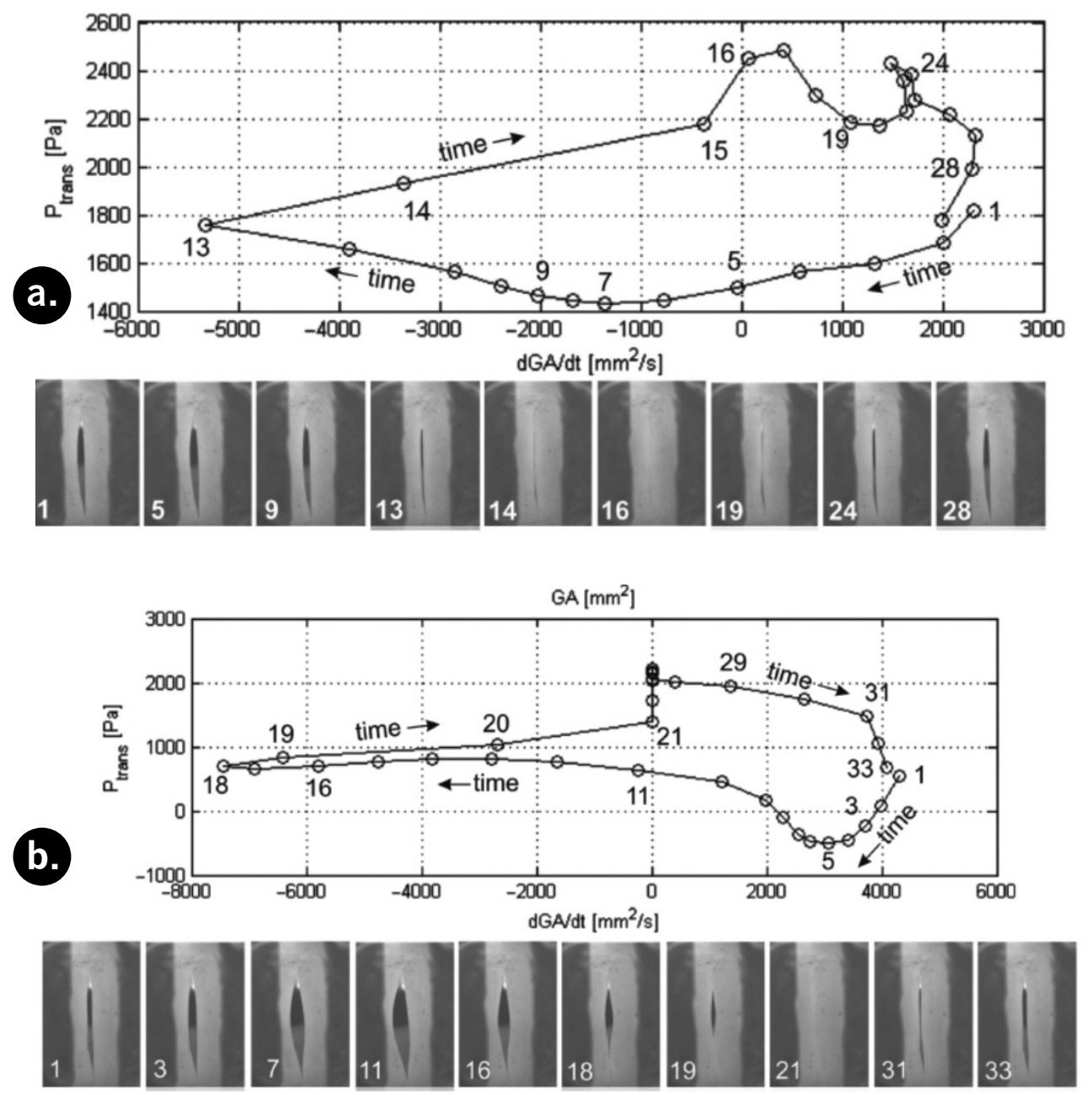


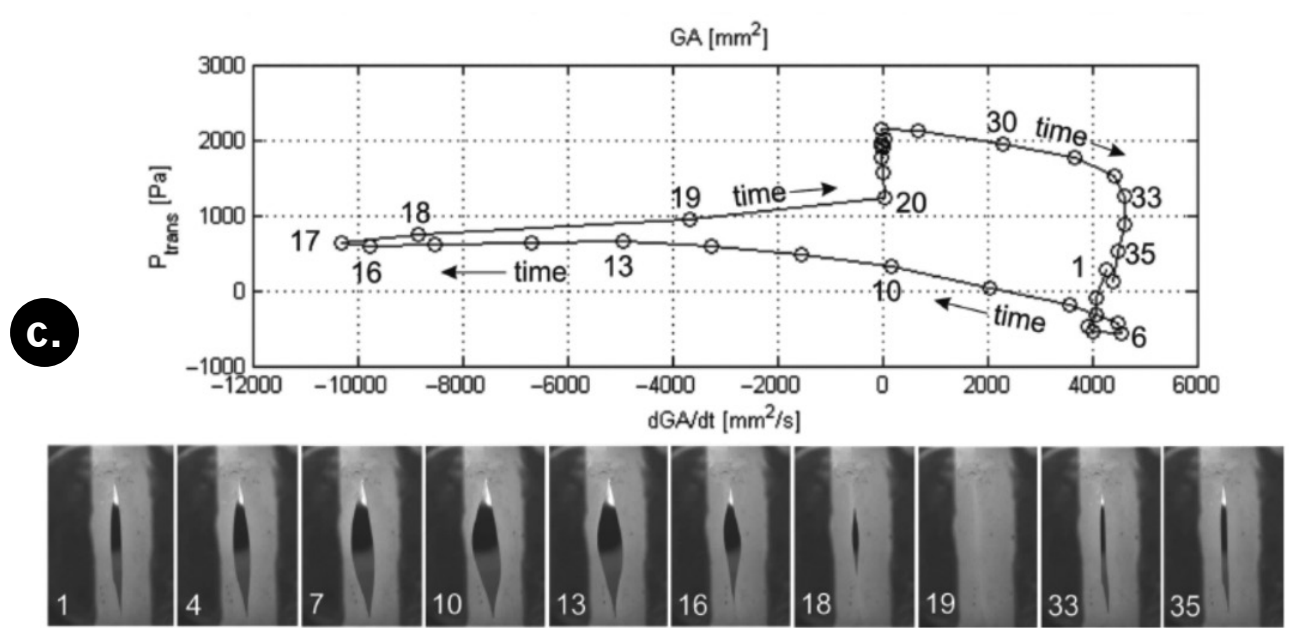

KUVA 4. Transglottaalisen ilmanpaineen ja glottiksen pinta-alan muutosnopeuden vaihtelu (silmukkaesitykset) äänihuulivärähdyksen aikana (kuvasarjat glottiksesta). Äänentuotto fysikaalisella mallilla (a) vokaalissa [u], (b) äännössä lasiseen resonanssiputkeen sen toinen pää ilmassa, ja (c) äännössä resonanssiputkeen, jonka toinen pää on upotettu $10 \mathrm{~cm}$ veteen. Kuvat muokattu artikkelista Horáček J, Radolf V, Laukkanen A-M. Experimental and computational modeling of the effects of voice therapy using tubes. JSHLR 2019 painossa.

Optimaalinen äänentuotto syntyy silloin, kun ääntöväylän ja äänihuulten vastus ovat sopivassa suhteessa keskenään. Kurkunpääputken (äänihuulista kurkunkansipoimuun ulottuva osa ääntöväylää) suhteellinen kapeutuminen alanielun läpimittaan nähden (aikaansaatavissa esimerkiksi kurkunpään pienellä alentamisella tai nielun avartamisella, esim. mielikuva alkavasta haukotuksesta) voi nostaa väylän inertiivistä reaktanssia laajalla taajuusvaihtelualueella (Titze \& Story, 1997). Se voi myös tuottaa ns. lauluformantin tai puhujanformantin eli resonanssien yhteen sulautuman, joka aikaansaa voimakkaan äänienergiaesiintymän edellisessä tapauksessa 2000-3000 Hz alueelle, jälkimmäisessä 3000-4000 Hz alueelle (Laukkanen \& Leino, 1999; Leino, Laukkanen \& Radolf, 2011). Tämä äänienergiaesiintymä saa klassisessa oopperalaulussa (mies)laulajan äänen kuulumaan orkesterin yli. Puheessa puhujanformantti lisää äänen 'soivuutta' ja kantavuutta. On oletettavaa, että esimerkiksi ääntöväylää ahtauttavien harjoitusten aikana harjoittelija saa kokemuksen positiivisesta ääntöväylävaikutuksesta, ja se auttaa häntä oppimaan kurkunpääputken ahtauttamisen, millä voi tavoittaa vastaavanlaisen tuntemuksen äännössä kuin väylää ahtauttavan harjoituksen aikana.

Klassisessa laulukoulutuksessa opetellaan hyödyntämään akustis-mekaanista vuorovaikutusta ja välttämään sen haittoja. Naislaulajat laskevat alaleukaa sitä enemmän, mitä korkeampia sävelkorkeuksia he laulavat. Sillä tavoin ääntöväylän matalin resonanssi saadaan nostetuksi lähelle perustaajuutta (erityisesti laulettaessa niin korkeilla sävelkorkeuksilla, että ne ylittävät kyseessä olevan vokaalin matalimman resonanssitaajuuden). Aivan korkeimmilla sävelkorkeuksilla ja henkilöstä riippuen voidaan pyrkiä nostamaan 
myös väylän toista resonanssia, esimerkiksi työntämällä kieltä eteenpäin. Myös suupielten vetäminen hymyasetukseen auttaa nostamaan väylän resonanssitaajuuksia. Tenorit pyrkivät nostamaan ääntöväylän matalimman resonanssin hyvin selvästi perustaajuuden yläpuolelle (esim. kolmannelle osasävelelle) myös korkeita sävelkorkeuksia laulaessaan (Titze \& Worley, 2009). Tällä tavoin ääni säilyttää miehekkään sointivärin (resonanssin ollessa lähempänä perustaajuutta ääni on puolestaan falsetinomainen, naislaulajalle tai kontratenorille tyypillinen). Äänihuulivärähtelyä haittaavien ääntöväylän ja henkitorven resonanssien vaikutusta voidaan harjoittelun avulla opetella minimoimaan esimerkiksi asettamalla äänihuulia tiiviimmin tai höllemmin yhteen tai muuttamalla vokaaliväriä ja siten siis ääntöväylän resonansseja (esim. korkeammilla sävelkorkeuksilla lauletaan a:n ja u:n sijasta o-maisesti). Tiiviimpi äänihuulten lähentäminen stabiloi äänihuulivärähtelyä (esim. säilyttää värähtelymoodin rintarekisterissä). Höllempi äänihuulten lähentäminen vaimentaa haitallista resonanssia tai siirtää sen taajuutta, tai auttaa äänihuulivärähtelyä pysymään falsetissa/siirtymään falsettia kohden ('ohentaminen').

Matalien sävelkorkeuksien sointia ja kuuluvuutta voidaan parantaa laulussa samaten kuin puheessakin laskemalla ääntöväylän matalinta resonanssia lähemmäs perussäveltä. Käytännössä tämä tapahtuu väljissä vokaaleissa suun avaamista pienentämällä ja suppeissa vokaaleissa ahtauttamalla kielen muodostamaa kapeikkoa suussa. Myös kurkunpään lasku madaltaa resonanssitaajuuksia.

Ei-klassisessa laulussa käytetään toisenlaisia tekniikoita ääntöväylän hyödyntämisessä kuin klassisessa laulussa. Eräs esimerkki eiklassisesta laulusta on ns. belttaus. Se on voimakasta, rintarekisterissä pysyttäytyvää, jopa huudon kaltaiseksi kuvattua, sävelkorkeudeltaan suhteellisen korkeaa, suunnilleen c2-d2 asti, joskus jopa ylemmäs menevää laulua, jota käytetään mm. pop- ja musiikkiteatterilaulussa. 'Belttauksessa' nostetaan korkeimmilla taajuuksilla F1 maksimaalisen ylös, jotta se voimistaisi riittävästi äänen toista osasäveltä. Apuna käytetään kurkunpään nostoa ja voimakasta suun avaamista (Titze \& Worley, 2009; Titze, Worley \& Story, 2011).

\section{MILTÄ AKUSTINEN INTERAKTIO TUNTUU?}

Hyvän tuntuman akustiseen interaktioon voi saada seuraavalla tavalla. Äännä vaikkapa mehupilliin tai lasiputkeen (esimerkiksi ns. resonaattoriputkeen, ks. Simberg \& Laine, 2007; Sovijärvi, 1969), huulet tiiviisti pillin tai putken ympärillä. Tarkista sieraimia sulkemalla, että ilma ei virtaa nenästä, vaan ainoastaan huulien välistä pilliin tai putkeen. Anna sävelkorkeuden liukua hitaasti ylös ja alas. Voit tuntea, että joillakin sävelkorkeuksilla putki tuntuu tarjoavan mukavan vastuksen ilmavirtaukselle, jolloin ääni ikään kuin lepää eräänlaista tyynyä vasten, ja ääntä voi tuottaa varsin kauan, koska ilmaa tuntuu kuluvan tuskin ollenkaan. Tällöin sävelkorkeutesi on hieman ääntöväyläsi ja pillin/putken (todennäköisesti) matalimman resonanssin alapuolella, ja ääntöväylän positiivinen reaktanssi tukee äänihuulivärähtelyä. Sen sijaan hieman korkeammalla sävelkorkeudella tuntuu kuin pilli tai putki otettaisiin pois huulilta, eikä ääntöväylä enää tarjoa mukavaa vastusta ilmavirtaukselle. Sävelkorkeutesi on tällöin ylittänyt ääntöväyläsi ja pillin/putken matalimman resonanssin, eikä ääntöväylässä ole juuri sellaisella taajuudella positiivista reaktanssia, mikä tukisi äänihuulivärähtelyä. Lievemmässä muodossa tämän saman ilmiön voi kokea, kun vaihtaa vokaalia: Väljässä vokaalissa /a, ae/, ääntöväylän matalin resonanssi on suhteellisen korkealla taajuudella (n. 600-800 $\mathrm{Hz}$ ). Kun perustaajuutesi on puhekorkeusalu- 
eella esim. $100 \mathrm{~Hz}$ (miespuhuja) tai $200 \mathrm{~Hz}$ (naispuhuja), ääntöväylä ei anna mitään mainittavaa ilmavirtausvastusta. Sen sijaan suppeissa ja pyöreissä vokaaleissa /i, y, ö, u/ ääntöväylän alin resonanssi on suhteellisen matala (300-400 Hz), ja voit tuntea taas, miten väylä tarjoaa ilmavirtausvastusta, joka tukee äänihuulivärähtelyä. Laulu- ja puheteknisen koulutuksen myötä voit harjoitella saavuttamaan tämän ns. ääntöväylätuen tunteen vokaalista ja sävelkorkeudesta riippumatta. Tällöin mitä todennäköisimmin olet oppinut säätelemään kurkunpääputken ahtautta ja tuottamaan sen avulla ikään kuin puhallinsoittimen suukappaleen ääntöväylääsi. Sen avulla voit pitää yllä positiivista reaktanssia laajalla sävelkorkeusvaihtelualueella. Se helpottaa äänihuulivärähtelyä (alentaa äännön kynnyspainetta eli alinta painetta, jolla äänihuulet lähtevät värähtelemään ja värähtely pysyy yllä). Se myös lisää äänen voimakkuutta ja kuuluvuutta sekä stabiloi rekisterisiirtymiä.

\section{JOHTOPÄÄTÖKSET}

Ääntöväylän ja äänilähteen vuorovaikutus voi olla joko positiivista tai negatiivista (parantaa tai heikentää äänenlaatua ja lisätä tai heikentäääänen voimakkuutta).

Ääntöväylän akustiikan vaikutus äänihuulten välistä tulevaan virtauspulssiin voi voimistaa ääntä. Vuorovaikutusta tapahtuu, kun ääntöväylän vastus on riittävän suuri suhteessa äänihuulten vastukseen (voimaan, jolla äänihuulia lähennetään toisiaan kohden). Esimerkiksi kurkunpääputken suhteellinen ahtauttaminen (mm. sopivalla kurkunpään laskulla ja/tai nielun avartamisella) nostaa ääntöväylän vastusta (inertiivistä reaktanssia), joka voi myös tehostaa äänihuulivärähtelyä.

Äänen perustaajuuden tai jonkin sen kerrannaisen osuminen ääntöväylän resonanssitaajuudelle (esim. nostettaessa sävelkorkeutta) voi saada äänen pois kontrollista ja aiheuttaa tahattoman siirtymisen falsettirekisteriin (ns. 'breikki' tai 'kukko'). Samalla sävelkorkeus voi muuttua.

Äänen harjoittamisessa hyödynnetään akustis-mekaanista vuorovaikutusta: soinnilliset frikatiivit, suppeat vokaalit, nasaalit, putkiin ääntäminen ja huulilla tai kielellä päristely lisäävät väylän ilmavirtausvastusta ja auttavat kohden taloudellisempaa ja tehokkaampaa äänentuottoa.

Klassisessa laulussa hyödynnetään akustismekaanista vuorovaikutusta: sävelkorkeuksilla yli e1:n naislaulajat nostavat ääntöväylän matalimman resonanssin hieman perustaajuuden yläpuolelle, ja lisäävät siten merkittävästi äänen kuuluvuutta.

Akustis-mekaanisen vuorovaikutuksen toteutumisen määrää voi säädellä muuttamalla äänihuulten yhteen saattamisen tiiviyttä tai perustaajuuden ja resonanssien suhdetta (sävelkorkeutta tai ääntöväyläasetusta, esim. vokaaliväriä, muuttamalla) ja kurkunpääputken läpimittaa. Kun kurkunpääputki on hyvin ahdas, vuorovaikutus on suurin.

\section{Kiitokset}

Kiitämme Päivi Svärdiä (Tampereen yliopisto) ja graafikko Senni Vesteristä julkaisun kuvien muokkaamisesta. Tämä katsausartikkeli on undistettu ja täydennetty versio aikaisemmin kirjassa Pubuva ibminen. Pubetieteiden perusteet julkaistusta artikkelista Ä̈nilähteen ja -väylän vuorovaikutus (Laukkanen, 2009). Muokattu versio julkaistaan aiemman version kustantajan (Otava) luvalla. 


\section{LÄHTEET}

Alku, P. (2011). Glottal inverse filtering analysis of human voice production $-\mathrm{A}$ review of estimation and parameterization methods of the glottal excitation and their applications. Sadhana, 36, 623-650.

Echternach, M., Markl, M. \& Herzel, H. (2011). Vocal tract configurations in yodelling-prospective comparison of two Swiss yodeller and two non-yodeller subjects. Logopedics Phoniatrics Vocology, 36, 109-113.

Fant, G. (1960). Acoustic theory of speech production. The Hague: Mouton.

Fant, G. \& Lin, Q. (1987). Glottal source-vocal tract acoustic interaction. STL-QPSR, 1,13-27.

Herzel, H., Berry, D., Titze, I. R. \& Saleh, M. (1994). Analysis of vocal disorders with methods from nonlinear dynamics. Journal of Speech, Language, and Hearing Research, 37, 1008-1019.

Horáček, J., Radolf, V. \& Laukkanen, A.-M. (2017). Low frequency mechanical resonance of the vocal tract in vocal exercises that apply tubes. Biomedical Signal Processing and Control, 37: 39-49.

Horáček, J., Radolf, V., Laukkanen, A.-M. (2019, painossa). Experimental and computational modeling of the effects of voice therapy using tubes. Journal of Speech Hearing Language Research. https://doi.org/10.1044/2019_ JSLHR-S-17-0490

Horáček, J., Radolf, V., Laukkanen, A.-M. (2018). Impact stress in water resistance voice therapy. A physical modelling study. Journal of Voice in press. https://doi.org/10.1016/j. jvoice.2018.01.025

Jiang,J.J., Titze, I.R. (1994). Measurement of vocal fold intraglottal pressure and impact stress, Journal of Voice 8:132-144.

Laine,U.K. (1982). Modelling of lip radiation impedance in $\mathrm{z}$-domain. Proceedings of the ICASSP, vol. 7, 1992-1995.

Laine, U. \& Vilkman, E. (1987). Acousticmechanical feedback in vocal source - tract interaction. Proceedings of the XIth International Congress of Phonetic Sciences. August 1-7, 1987 , Tallinn, Estonia, vol. V, 19-22.
Laukkanen, A.-M. (2009). Äänilähteen ja -väylän vuorovaikutus. Teoksessa O.

Aaltonen, R. Aulanko, A. Iivonen, A. Klippi \& M. Vainio (toim.), Puhuva ihminen. Puhetieteiden perusteet, (s 183-190). Helsinki: Otava.

Laukkanen, A.-M. \& Leino, T.(1999). Ibmeellinen ihmisääni. Helsinki: Gaudeamus.

Leino, T., Laukkanen, A.-M. \& Radolf, V. (2011). Formation of the actor's/speaker's formant: A study applying spectrum analysis and computer modeling. Journal of Voice, 25, 150-158.

Mergell, P. Herzel, H. (1997). Modelling biphonation - The role of the vocal tract. Speech Communication, 22,141-154.

Müller, J. (1837). Handbuch der Physiologie der Menschen. Koblenz: Holscher.

Rothenberg, M. (1981). An interactive model for the voice source. $S T L-Q P S R$, 4.

Rothenberg, M. (1986). Cosí fan tutte and what it means or Nonlinear Source-Tract acoustic interaction in the soprano voice and some implications for the definition of vocal efficiency. teoksessa T. Baer, C. Sasaki \& K.S. Harris (toim.), Vocal fold physiology: Laryngeal function in phonation and respiration, (s. 254263). San Diego: College-Hill Press.

Story, B. H., Laukkanen, A-M. \& Titze, I. R. (2000). Acoustic impedance of an artificially lengthened and constricted vocal tract. Journal of Voice, 14, 455-469.

Sundberg, J. (1975). Formant technique in professional female singer. Acustica, 32, 89-96.

Titze, I. R. (1988). A framework for the study of vocal registers. Journal of Voice, 3, 183-194.

Titze, I. R. (1998). Deliberate use of distortion in singing, Journal of the Acoustical Society of America, 103, 2796.

Titze, I. R. (2000). Principles of Voice Production. Iowa City: National Center for Voice

and Speech; http://books.google.fi/ books?id=ytAeAQAAMAAJ.

Titze I. R. (2008). Non-linear source-filter coupling in phonation: Theory. Journal of the Acoustical Society of America, 123, 2733-2749.

Titze, I.R. \& Laukkanen, A.-M. (2007). Can vocal economy in phonation be increased with an artificially lengthened vocal tract? A computer modelling study. Logopedics Phoniatrics Vocology, 32,147-156. 
Titze, I. R. \& Story, B. H. (1997). Acoustic interactions of the voice source with the lower vocal tract, Journal of the Acoustical Society of America, 101, 2234-2243.

Titze, I. R. \& Worley, A. S. (2009). Modeling source-filter interaction in belting and highpitched operatic male singing. Journal of the Acoustical Society of America, 126, 1530-1540.

Titze, I. R., Worley, A. S. \& Story, B. H. (2011). Source-Vocal Tract Interaction in Female Operatic Singing and Theater Belting. Journal of Singing, 67, 561-572. 


\section{OVERVIEW ON VOICE SOURCE - VOCAL TRACT INTERACTION}

Anne-Maria Laukkanen, Speech and Voice Research Laboratory, Faculty of Social Sciences, University of Tampere

Unto K. Laine, Department of Signal Processing and Acoustics, Aalto University

Speech and voice production is still often seen through a traditional model with four independent components: respiratory system, vocal folds, vocal tract and the lips. In reality, however, the resonator, formed by the vocal tract, is in interaction with both of its endings: the vocal folds and the lips. This article makes a review on the main types of interaction and gives examples of them. Through the examples it is possible to state how the interaction takes place in voice exercises and therapy methods, artistic voice use and voice disorders. Practical examples help to find out how the interaction feels in the body.

Keywords: hoarseness, impedance, reactance, resonance, singing, voice therapy 